\title{
ANALYSIS OF THE 5S METHOD FUNCTIONING IN A PRODUCTION COMPANY
}

\author{
Radosław WOLNIAK \\ Silesian University of Technology, Faculty of Organization and Management, Institute of Economy and \\ Informatics; rwolniak@polsl.pl, ORCID: 0000-0003-0317-9811
}

Purpose: The goal of the paper is to analyses process of implementation and effectiveness of $5 \mathrm{~S}$ method in an industrial enterprise.

Design/methodology/approach: Critical literature analysis, questionnaire analysis, case study analysis.

Findings: On the example of industrial organization that was in the presented paper an analysis of effectiveness of $5 \mathrm{~S}$ implementation. On the basis of conducted analysis the main objectives of using $5 \mathrm{~S}$ are: order in the workplace, maintenance of cleanliness and efficiency of machines and devices, shorter duration of activities. The main causes of problems with $5 \mathrm{~S}$ implementation are connected with no time to do the work and lack of funds. The overall rating of efficiency of $5 \mathrm{~S}$ method in analyzed enterprise is very good.

Originality/value: Detailed analysis of main objectives of using $5 \mathrm{~S}$ method and the main causes of problems with it in the industrial enterprise.

Keywords: quality management, quality methods, 5S, quality improvement, quality tool, production management.

Category of the paper: research paper.

\section{Introduction $-5 \mathrm{~S}$ practice}

The paper concentrates on the description of the use of $5 \mathrm{~S}$ method in the industrial enterprise. The goal of the paper is to analyses process of implementation and effectiveness of $5 \mathrm{~S}$ method in an industrial enterprise.

The name of the method comes from five Japanese words that refer to systematic ordering, maintaining order and ergonomics at the workplace. The method consist of five following pillars (Juszczyńska, and Fogt, 2017; Wojakowski, and Warżołek, 2016; Gala, and Wolniak, 2013; Kamińska, 2016; Waclawik, and Filipowicz, 2001; Mryczek, 2002; Piwowar, 2007; Pawlak, 2004; Gwiazda, 2010; Malinowska, 2011; Antypin, 2008; Karaś, and Rajchel, 2015; Wolniak, 2018; Wolniak, and Skotnicka, 2011; Gębczyńska, and Wolniak, 2018; Sułkowski, 
and Wolniak, 2018; Łuczak, and Wolniak, 2015; Skotnicka-Zasadzień, et al., 2017; Wolniak, and Skotnicka-Zasadzień, 2014; Olkiewicz, et al., 2017; Łuczak, and Wolniak, 2016; Pacana, 2016):

- $1 \mathrm{~S}$ - Seri (sort) - the stage at which the objects are sorted into necessary and unnecessary to implement production assumptions. Unnecessary items are marked with red cards, separated and discarded or scrapped. Similarly, the elements that we have doubts are separated and subjected to the assessment of usefulness. Selection allows you to create such an environment work in which space, time, money, energy and other resources will be can be used in the most effective way. Employees during the selection are equipped with red cards and stick them on every item that in their opinion, he should not be in the given job. All items marked with a red label can be stored in a designated place, called the red label store, which acts as a "waiting room" for items that are currently unnecessary.

- $2 \mathrm{~S}$ - Seiton (set in order) - determining the place and determining how to store everything that a given unit requires to operate (tools, semi-finished products, raw materials, materials, means of transport, documents). Creating positions with convenient access to the things needed at the moment. The stage aims to create ergonomic, well-maintained stands and increase efficiency. The first stage in the process of implementing seiton is choosing the right one location. The basic techniques of visual control include here: clearly defined storage areas (lines, plates, labels, placement fields), color marking, arrow marking, marking the maximum and minimum levels for materials for production, for finished products and goods, and so-called shadow boards. On the shadow board, each tool is placed in a designated place, which allows you to instantly identify the absence of any of them and determine the routine for picking and putting away each tool. By introducing it, you can avoid such problems:

$\circ$ traffic-related waste,

- search waste - no one could find the key,

o waste of excessive inventory.

- $3 \mathrm{~S}$ - Seiso (shine) - elimination of dirt, dust and contaminations resulting from production processes, keeping the station and tools clean. Work schedules related to daily order maintenance should be created. The implementation of the third S principle through regular organization of the workplace should be included in the scope of daily duties of the operator (owner) of a given position and performed by him personally. In addition to the obvious premises (maintaining order and good condition of machines, devices, work items), the very process of cleaning the workplace together with its equipment and used machines also gives the opportunity to identify anomalies and detect potential problems that usually remain unnoticed when only a cursory view of the workplace. Everyday supervision of critical points of machines by operators allows them to be able to observe the operation of the machine and quickly detect even minor irregularities. 
- $4 \mathrm{~S}$ - Seiketsu (standardization) - Making earlier 3S become a habit. It is to create standards for previous stages and to monitor them. Creating cleaning and inspection plans. Defining standards aims to achieve a situation in which all workstations will be transparent and visually marked so that a change in the scope of duties for the employee will only involve a short training, and the identification of deviations from the set standard will be very quick. Standards for the placement and marking of tools, work objects, materials and any other equipment for the workstations should be generally known and common to the entire enterprise. Standards and procedures must be clear, simple and very easy to understand, which is why $5 \mathrm{~S}$ good practices include the widest possible involvement of employees in a given area to develop them. Due to the fact that it is the employees carrying out the work best know the specifics of activities in their position, they are able to create the best instructions and standards, and thus better understand the essence of changes and constantly improve.

- $5 \mathrm{~S}$ - Shitsuke (self-discipline) - compliance with previously set standards, improvement of $5 \mathrm{~S}$ activities. No matter how well we implement the first four pillars, the $5 \mathrm{~S}$ system will not function long without commitment in its maintenance. Developing new habits is a long-term process and demanding considerable effort, because it involves the way of thinking and change of current practices and habits. For this reason, self-discipline is often referred to as the most difficult element to implement in the $5 \mathrm{~S}$ approach, because it involves the need to change the way of thinking and change existing practices and habits. Such deep changes in the company's organizational culture often require a broad commitment of the company's top management.

Both the five pillars of S and the seven types of waste have direct impact on product quality and work safety. The implemented $5 \mathrm{~S}$ leads to the reduction or elimination of defects, waste, breakdowns or accidents at work. However, the beneficial effects of the method are rarely exposed on the environment (Czajkowska, 2017; Gajdzik, 2017; Michalska, and Szewieczek, 2007; Antonowicz, 2013; Bielecki, and Wiśniewska, 2008; Gajdzik, 2008; Kleszcz, 2017; Gajdzik, and Wyciślik, 2016, Bator, and Paluchniak, 2013; Piasecka-Głuszczak, 2010). However, the experience of many companies related with the use of $5 \mathrm{~S}$ indicates an improvement in efficiency also in terms of environmental activities. For this reason, organizations decide to use lean manufacturing tools along with $5 \mathrm{~S}$ for both improvement in terms of quality as well as environmental and real management system limiting negative impact on the environment. Deciding on implementation of lean manufacturing assumptions, enterprises often start with the $5 \mathrm{~S}$ tool, as it is the foundation of the future activities for continuous improvement of the organization (Lipiak, and Krystosiak, 2014; Pacana, et al., 2014; Mucha, and Nowosielski, 2018; Kowalski, and Ilska, 2018, Gundlach, 2009). 


\section{Methodology}

The analysis conducted in this paper was done on the example of one Silesian production enterprises. The $5 \mathrm{~S}$ method is undoubtedly one of the most important Lean tools used in the enterprise. Its elements are visible throughout the entire plant, i.e. warehouses, production departments, communication routes and offices.

Applying the 5S rules when storing these elements significantly facilitates the work of operators:

- Reduces the changeover time - the operator who performs retooling operations has the necessary tools and parts at hand. Sorted in categories according to the order of their activities.

- Limits unnecessary movement - the operator does not have to look for tools, and arranging them in an ergonomic way reduces unnecessary physical effort (bending, moving, etc.).

- Allows better use of space - the introduction of multi-level trolleys and tool containers reduces the space for storage.

- Keeps tools working - the use of specific markings for specific tools makes it easier to identify defective tools and any missing items.

The material for analysis is the results of a survey conducted on the PCDKDZ section regarding the effectiveness of the implemented $5 \mathrm{~S}$ system. Fifty participants were asked to participate in the survey, including 27 on worker positions and 3 actively participating in section audits. The questions to which the interviewers provided answers were related to the effectiveness of the application of this method, the benefits arising from compliance with its principles and knowledge of the pillars forming 5S. The obtained results have been presented in the form of charts.

\section{5S functioning - an example}

The first question concerned the goals which, according to the respondents, resulted in the use of the $5 \mathrm{~S}$ method. $22.2 \%$ of respondents indicated that the $5 \mathrm{~S}$ method improves order at work places, while $15.6 \%$ thinks that the method is important for maintaining cleanliness and efficiency of machines and devices, as well as shorter duration of activities. $13.3 \%$ of the answers were that using this method tools in the production are easy to find, and $11.1 \%$ say about improved ergonomics. A good image in the eyes of the customer and increased security were recognized by $6.7 \%$ workers. The least points were obtained by eliminating waste $-3.3 \%$ (Fig. 1). 


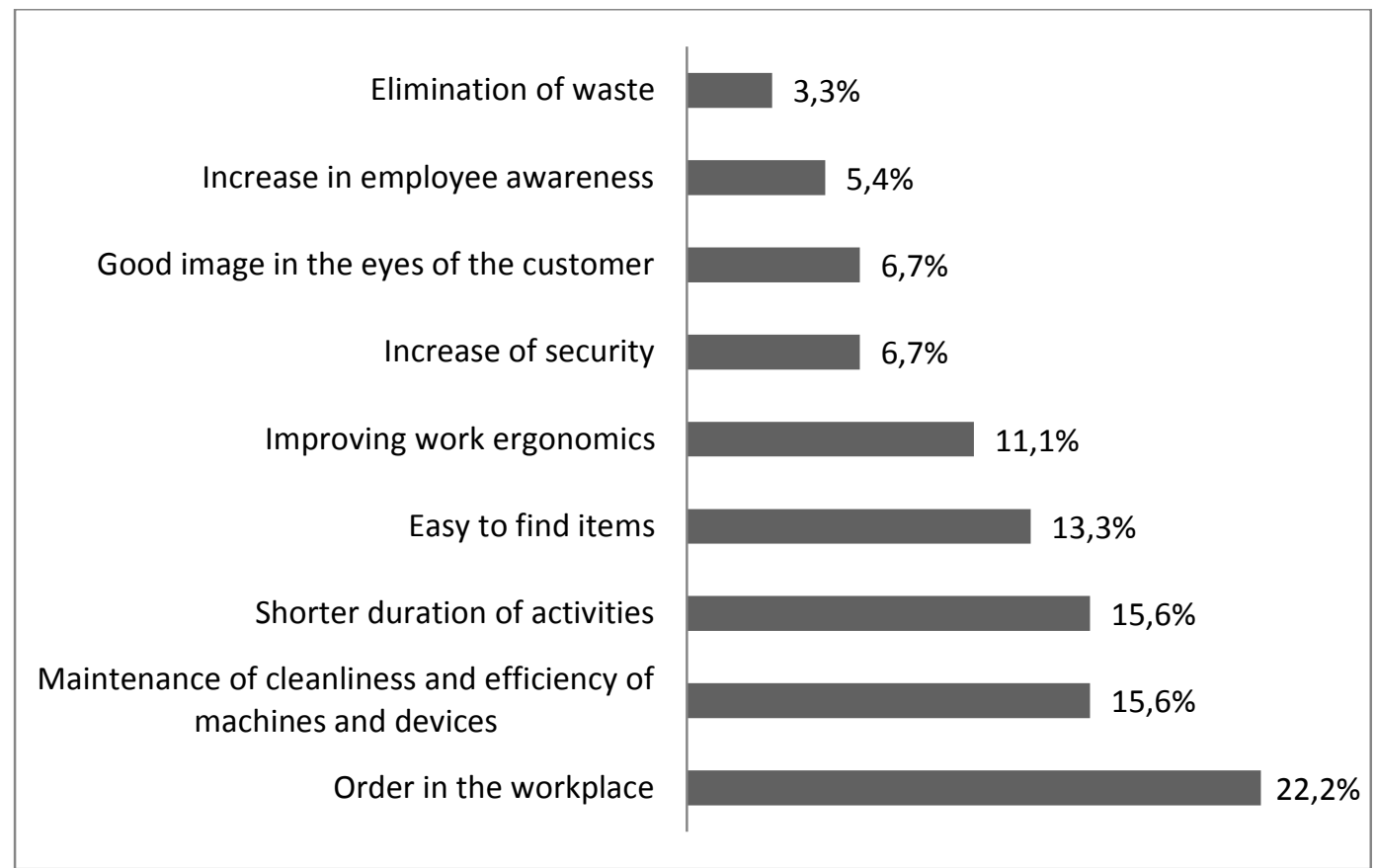

Figure 1. Objectives achieved through the use of 5S. Source: (Wilk, 2019).

The next question asked in the survey concerned the main causes of errors made in the works specified by $5 \mathrm{~S}$. Most respondents considered the reason for errors the lack of time to carry out work related to $5 \mathrm{~S}$ with a result of $64.4 \% .16 .7 \%$ indicated a lack of funds. $12.2 \%$ of respondents said that they lack training, $6.7 \%$ of tasks are incorrectly allocated. None of the respondents considered errors at the stage of implementing $5 \mathrm{~S}$ as the reason of problems with work (Fig. 2).

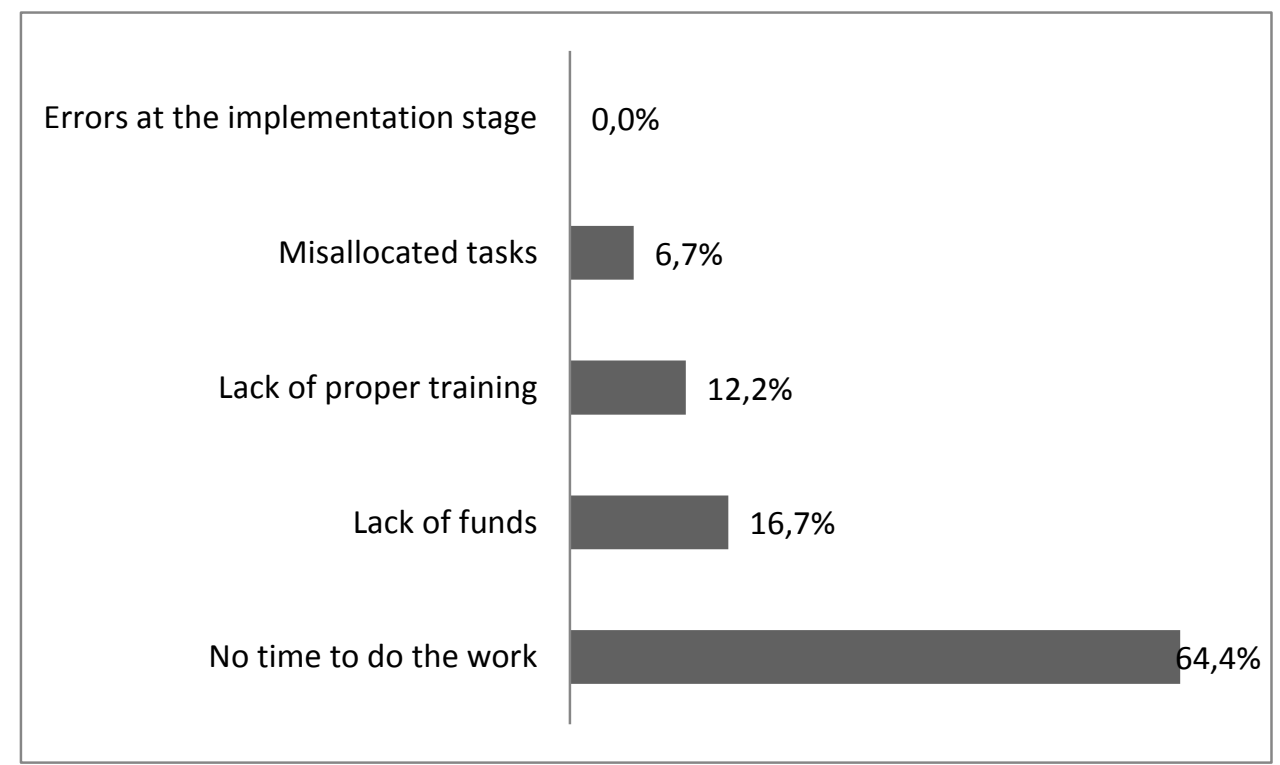

Figure 2. Causes of errors in the work of 5S. Source: (Wilk, 2019).

The last question concerned the determination of the effectiveness of the $5 \mathrm{~S}$ method used at the plant. In conducted survey $82.2 \%$ rated the effectiveness at a very good level, $12.2 \%$ at a good level. Only $5.6 \%$ of respondents gave the answer "average". The level below average was not marked by any person (Fig. 3). 


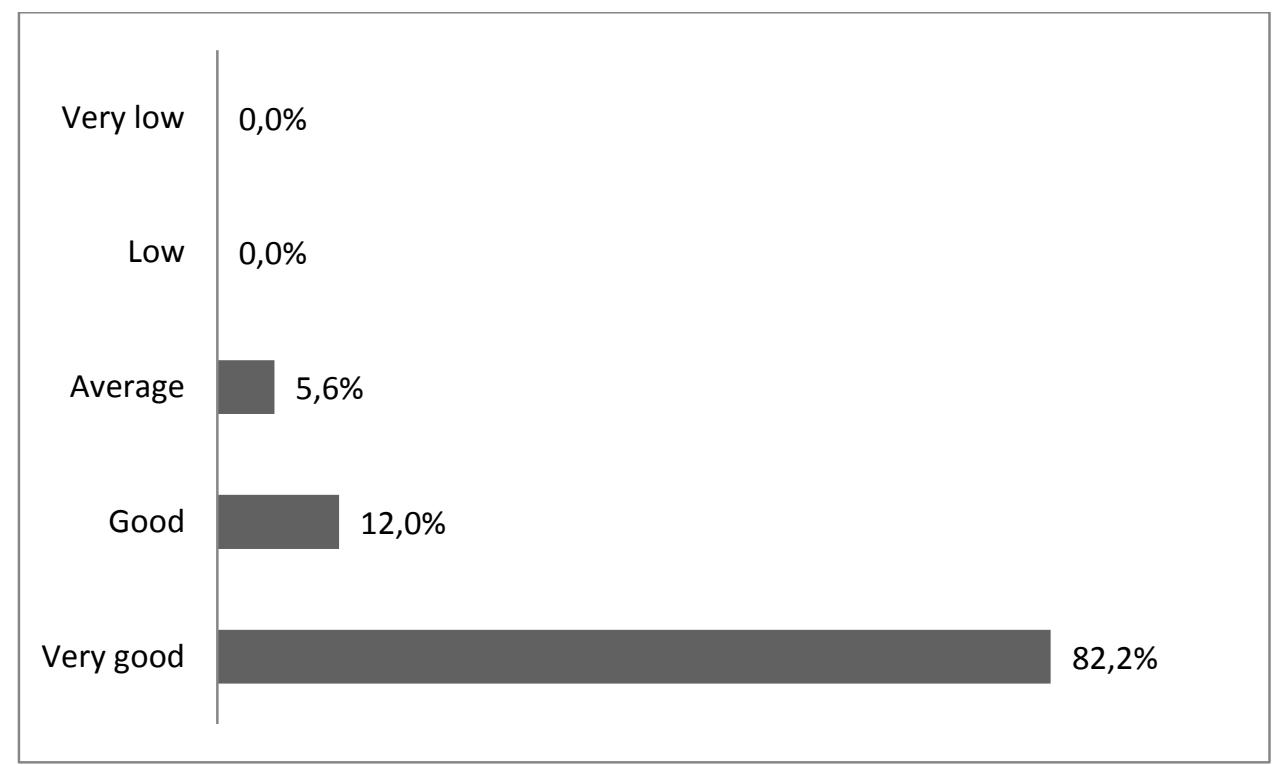

Figure 3. The efficiency of the 5S method. Source: (Wilk, 2019).

The next stage is the analysis of the results of weekly 5S audits on the PCDKDZ section hereinafter referred to as $5 \mathrm{~S}$ patrols and the share of results in individual $5 \mathrm{~S}$ pillars. As mentioned earlier, each department is required to periodically audit this method. The data for further analysis are the results of patrols from 2018, carried out regularly every Thursday on the first shift (Fig. 4).

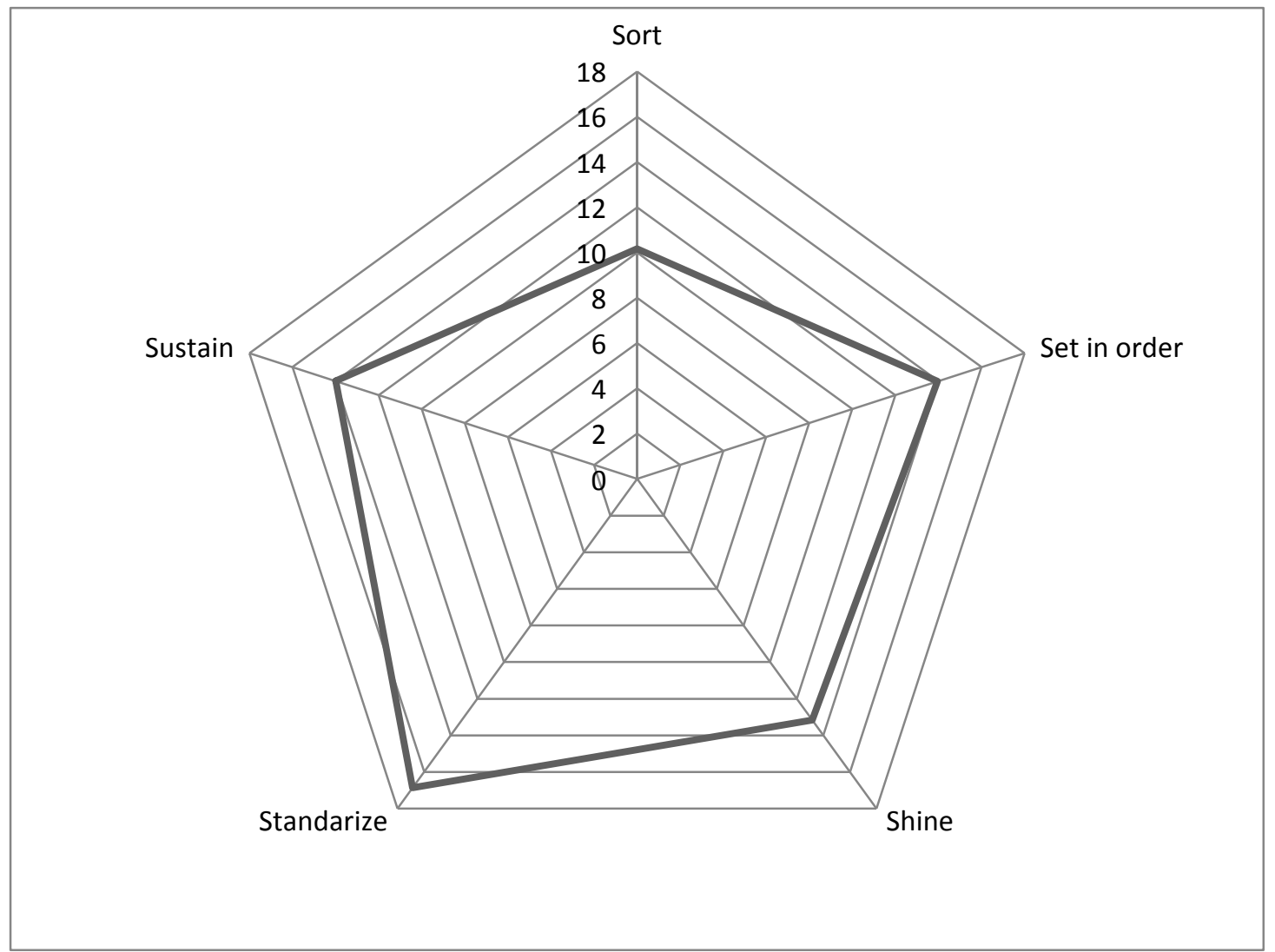

Figure 4. The average result of $5 \mathrm{~S}$ patrols in individual pillars on the PCDKDZ section. Source: (Wilk, 2019). 


\section{Summary}

$5 \mathrm{~S}$ is the basic Lean Management tool, allowing not only to create and maintain well-organized work positions, but above all to increase the stability of work in these positions. Strictly defined and permanent storage locations for tools, instruments, documents and other work items, established routines, proper presentation of material for production employees, predictable performance and visual control over processes are a good basis for implementing more advanced Lean solutions.

On the example of industrial organization that was in the presented paper an analysis of effectiveness of $5 \mathrm{~S}$ implementation. On the basis of conducted analysis the main objectives of using $5 \mathrm{~S}$ are: order in the workplace, maintenance of cleanliness and efficiency of machines and devices, shorter duration of activities. The main causes of problems with $5 \mathrm{~S}$ implementation are connected with no time to do the work and lack of funds. The overall rating of efficiency of $5 \mathrm{~S}$ method in analyzed enterprise is very good.

\section{References}

1. Antonowicz, M. (2013). Praktyki 5S jako podstawa logistyczno-marketingowych rozwiązań w transporcie kolejowym. Infrastruktura Transportu, 2, 32-35.

2. Antypin, P. (2008). Opracowanie oraz wdrożenie systemu $5 \mathrm{~S} \mathrm{w}$ firmie motoryzacyjnej. Problemy Jakości, 2, 41-47.

3. Bator, A., Paluchniak, A. (2013). Wykorzystanie metody 5S do poprawy bezpieczeństwa pracy w kopalniach. Przegląd Górniczy, 9, 7-10.

4. Bielecki, M., Wiśniewska, A. (2008). Wykorzystanie wybranych technik i narzędzi TQM do wdrożenia praktyk 5S. Logistyka, 2, 45-56.

5. Czajkowska, K. (2017). 5S jako metoda budowania przewagi konkurencyjnej. Journal of Modern Management Process, 2, 27-35.

6. Gajdzik, B. (2008). Organizacja pracy w przedsiębiorstwie hutniczym zgodnie z zasadami 5S. Hutnik, Wiadomości Hutnicze, 2, 70-74.

7. Gajdzik, B. (2008). Zasady wdrażania techniki 5S w urzędach miast i gmin. Problemy Jakości, 1, 37-40.

8. Gajdzik, B., Wyciślik, A. (2016). Ramowe zasady implementacji metody 5S w laboratorium chemicznym. Przemyst Chemiczny, 2, 176-179.

9. Gala, B., Wolniak, R. (2013). Problems of Implementation 5S Practices in an Industrial Company. Management Systems in Production Engineering, 4, 8-14. 
10. Gębczyńska, A., Wolniak, R. (2018). Process management level in local government. Philadelphia.

11. Gundlach, M. (2009). Praktyki 5S jako pierwszy krok do wdrożenia produkcji odchudzonej w przedsiębiorstwie produkcyjnym rozwinięcie teorii 6S. Zeszyty Naukowe. Organizacja i Zarządzanie, Politechnika Łódzka, 45, 19-40.

12. Gwiazda, A. (2010). Ewolucja metody 5S. Ekonomika i Organizacja Przedsiębiorstwa, $3,30-37$.

13. Juszczyńska, P., Fogt, M. (2017). 5S z życia wzięte - czyli jak wdrożyć 5S w domu. Zeszyty Studenckie Wydziału Ekonomicznego Nasze Studia, 8, 99-111.

14. Kamińska, A. (2016). Praktyczne zastosowanie 5S w wybranych fabrykach branży motoryzacyjnej. Studia Oeconomica Posnaniensia, 10, 134-144.

15. Karaś, E., Rajchel, D. (2015). Poprawa warunków realizacji produkcji i logistyki z wykorzystaniem metody kaizen i programu 5S. Logistyka, 6, 672-680.

16. Kleszcz, D. (2017). Assessment of application of 5S practices in ceramic industry. Production Engineering Archives, 16, 47-51.

17. Kowalski, D.J., Ilska, A. (2018). Metoda 5S jako fundament efektywnego procesu optymalizacji przedsiębiorstwa. Przegląd Włókienniczy - Włókno, Odzież, Skóra, 8, 19-22.

18. Lipiak, J., Krystosiak, K. (2014). "5S" we wspomaganiu zarządzania jakością w przedsiębiorstwie opakowaniowym. Ekonomika $i$ Organizacja Przedsiębiorstwa, 12, 120-127.

19. Łuczak, J., Wolniak, R. (2015). Problem-solving and developing quality management methods and techniques on the example of automotive industry. Manager, 22, 237-250.

20. Łuczak, J., Wolniak, R. (2016). Integration of quality environment and safety management systems in a foundry. Metalurgija, 4, 843-845.

21. Malinowska, E. (2011). Metoda 5S a system bezpieczeństwa żywnościowego. Zeszyty Naukowe, Uniwersytet Ekonomiczny w Poznaniu, 206, 45-54.

22. Michalska, J., Szewieczek, D. (2007). The 5S methodology as a tool for improving the organization. Journal of Achievements in Materials and Manufacturing Engineering, 2, 211-214.

23. Mryczek, B. (2002). Metoda 5S. Gospodarka Materiałowa i Logistyka, 2, 16-17.

24. Mucha, D., Nowosielski, S. (2018). Doskonalenie procesów w przedsiębiorstwie produkcyjnym z użyciem metody 5S. Marketing i Rynek, 12, 303-313.

25. Olkiewicz, M., Bober, B., Wolniak, R. (2017). Innowacje w przemyśle farmaceutycznym jako determinanta procesu kształtowania jakości życia. Przemyst Chemiczny, 11, 2199-2201.

26. Pacana, A. (2016). Metoda 5S. Częstochowa: Oficyna Wydawnicza Stowarzyszenia Menedżerów Jakości i Produkcji.

27. Pacana, A., Gazda, A., Wołoszyn, P. (2014). Wykorzystanie metody 5S do doskonalenia procesów logistycznych. Modern Management Review, 2, 73-80. 
28. Pawlak, W. (2004). O "Praktykach 5S" ponownie. Problemy Jakości, 4, 42-46.

29. Piasecka-Głuszak, A. (2010). Praktyki 5S jako jedna z metod zarządzania kaizen. Zeszyty Naukowe, Uniwersytet Ekonomiczny w Poznaniu, 157, 163-174.

30. Piwowar, K. (2007). Samodoskonalenie na 5S. Marketing w Praktyce, 3, 86-89.

31. Skotnicka-Zasadzień, B., Wolniak, R., Zasadzień, M. (2017). Use of quality engineering tools and methods for the analysis of production processes - case study. Advances in Economic, Business and Management Research, 33. Second International Conference on Economic and Business Management, FEBM, Shanghai, 240-245.

32. Sułkowski, M., Wolniak, R. (2018). Poziom wdrożenia instrumentów zarzadzania jakościa w przedsiębiorstwach branży obróbki metali. Częstochowa: Oficyna Wydawnicza Stowarzyszenia Menedżerów Produkcji i Jakości.

33. Wacławik, Ł., Filipowicz, P. (2001). Metoda "5S". Ekonomika i Organizacja Przedsiębiorstwa, 5, 26-30.

34. Wilk, M. (2019). Analiza funkcjonowania Lean Management w przedsiębiorstwie branży samochodowej. Praca dyplomowa napisana pod kierunkiem R. Wolniaka, Katowice.

35. Wojakowski, P., Warżołek, D. (2016). Wdrożenie 5S w przedsiębiorstwie produkcyjnym z branży motoryzacyjnej. Gospodarka Materiałowa i Logistyka, 11, 320-331.

36. Wolniak, R. (2018). Basic concepts of operation management and its control. Gliwice: Wydawnictwo Politechniki Śląskiej.

37. Wolniak, R., Skotnicka, B. (2011). Metody i narzędzia zarządzania jakościa - Teoria i praktyka, cz. 1. Gliwice, Wydawnictwo Naukowe Politechniki Śląskiej.

38. Wolniak, R., Skotnicka-Zasadzień, B. (2014). The use of value stream mapping to introduction of organizational innovation in industry. Metalurgija, 4, 709-712. 